\title{
HUBUNGAN ASUPAN KARBOHIDRAT, LEMAK,DAN PROTEIN DENGAN STATUS GIZI \\ (Studi Kasus pada Pekerja Wanita Penyadap Getah Karet di Perkebunan Kalijompo Jember)
}

\author{
Nabila Permata Siwi ${ }^{1}$, Indriati Paskarini ${ }^{2}$ \\ 1,2 Departemen Keselamatan dan Kesehatan Kerja \\ Fakultas Kesehatan Masyarakat Universitas Airlangga \\ Alamat korespondensi: Nabila Permata Siwi \\ Email: nabilapermata86@gmail.com
}

\begin{abstract}
Kalijompo Plantation is one of rubber plantations in Jember. One of rubber production is rubber tapping that is done not only by male but also female workers. One of the factors that can affect productivity is nutrition status. Nutrition status is influenced by the adequancy of nutrients, especially carbohydrates, fats, and proteins as energy producers. The purpose of this research was to study the correlation between carbohydrates, fats, and proteins intake with nutrition status in female tap rubber workers of Kalijompo Plantation in Jember. This research was analytical observational research and had a cross sectional design. The population of this research were all female tap rubber workers of Kalijompo Plantation in Jember with the sample consisted of 33 respondents. The variables of this research carbohydrates intake, fats intake, proteins intake, and nutrition status. Data collection included measurement of weight body, measurement of height body, and food recall $1 \times 24$ hours. The results showed that there was no correlation between carbohydrates intake with nutrition status $(p=0.968)$, there was no correlation between fats intake with nutrition status $(p=0.646)$, and there was no correlation between proteins intake with nutrition status $(p=0.679)$. The conclusion of this research was the intake of carbohydrates, fats, and proteins are not factors that can affect good or bad nutrition status in female rubber tapping workers of Kalijompo Plantation in Jember.
\end{abstract}

Keywords : carbohydrates intake, fats intake, protein intake, nutrition status.

\begin{abstract}
ABSTRAK
Perkebunan Kalijompo merupakan salah satu perkebunan karet di Kabupaten Jember. Salah satu aktivitas produksi karet adalah penyadapan getah karet yang dilakukan oleh pekerja laki-laki dan wanita. Salah satu faktor yang mempengaruhi produktivitas kerja adalah status gizi. Status gizi dipengaruhi oleh kecukupan zat gizi khususnya karbohidrat, lemak, dan protein sebagai penghasil energi. Tujuan dari penelitian ini adalah mempelajari hubungan antara asupan karbohidrat, lemak, dan protein dengan status gizi pekerja wanita penyadap getah karet di Perkebunan Kalijompo Jember. Penelitian ini merupakan penelitian observasional analitik dan memiliki rancang bangun cross sectional. Populasi penelitian ini adalah seluruh pekerja wanita penyadap getah karet di Perkebunan Kalijompo Jember dengan sampel penelitian berjumlah 33 responden. Variabel penelitian adalah asupan karbohidrat, asupan lemak, asupan protein, dan status gizi. Pengumpulan data meliputi penimbangan berat badan, pengukuran berat badan, dan foood recall 1x24 jam. Hasil penelitian ini menunjukkan bahwa tidak terdapat hubungan antara asupan karbohidrat dengan status gizi $(p=0,968)$, tidak terdapat hubungan antara asupan lemak dengan status gizi $(p=0,646)$, dan tidak terdapat hubungan antara asupan protein dengan status gizi $(p=0,679)$. Kesimpulan penelitian ini adalah asupan karbohidrat, lemak, dan protein bukan merupakan faktor yang dapat berpengaruh terhadap baik atau buruknya status gizi pada pekerja wanita penyadap getah karet di Perkebunan Kalijompo Jember.
\end{abstract}

Kata kunci : asupan karbohidrat, asupan lemak, asupan protein, status gizi

\section{PENDAHULUAN}

Salah satu komoditi perkebuan yag menduduki posisi cukup penting di Indonesia sebagai sumber devisa non migas adalah karet. Ekspor karet yang dilakukan Indonesia ke luar negeri mencapai 1.874 ton dengan nilai ekspor terbesar yaitu 2.181 juta U\$D pada tahun 2012 (BPS, 2013). Karet (Havea 
brasiliensi) merupakan tanaman yang menghasilkan getah, disebut lateks dan selanjutnya diolah menjadi karet alam di beberapa unit pabrik pengolah karet. Kualitas produksi karet yang dihasilkan ditentukan oleh bahan baku, teknologi pengolahan, sumber daya pekerja, dan lainnya (Yudhantara, 2015).

Salah satu faktor yang dapat menentukan kualitas produksi karet adalah sumber daya manusia. Produktivitas kerja yang baik berdampak positif terhadap hasil kerja. Produktivitas kerja dipengaruhi oleh faktor gizi. Gizi yang baik akan berdampak pada perfoma pekerja sehingga berdampak positif pada produktivitas kerjanya. Di beberapa negara berpenduduk padat dengan tingkat hidup yang relatif rendah, tersedianya tenaga kerja dalam jumlah berlebihan, tidak diikuti dengan kesejahteraan dan kebutuhan gizi yang baik, hal ini terutama pada tenaga kerja dari kelas bawah atau pekerja kasar. Masalah gizi pada pekerja contohnya adalah tingkat defisiensi gizi terutama energi dan defisiensi zat gizi mikro seperti vitamin. Keadaan tertentu yang dapat mendorong terjadinya gizi kurang pada tenaga kerja di Indonesia diantaranya adalah jam kerja yang panjang. Jam kerja yang dapat menyerap seluruh cadangan energi dalam tubuh. Lokasi pabrik yang jauh juga mengharuskan pekerja yang seringkali melewatkan makan pagi. Adanya pengawasan kerja yang sangat ketat, tidak memungkinkan bagi pekerja untuk berhenti sejenak untuk sarapan, sementara saat di perusahaan waktu istirahat yang disediakan sangat terbatas (Adriani dan Wirjatmadi, 2012).

Status gizi adalah keadaan kesehatan individu atau kelompok yang ditentukan oleh derajat kebutuhan fisik akan energi dan zat gizi lainnya yang diperoleh dari makanan yang dampak fisiknya diukur secara antropometri (Suhardjo, 2005). Status gizi juga dapat dikatakan sebagai keadaan keseimbangan antara asupan zat gizi dan kebutuhan zat gizi oleh tubuh untuk keperluan proses biologi. Keseimbangan zat gizi tersebut salah satunya dapat mempengaruhi aktivitas. Status gizi menjadi salah satu hal yang menentukan kualitas aktivitas bekerja atau produktivitas kerja seorang pekerja. Telah banyak dilakukan penelitian terkait hubungan antara status gizi dengan produktivitas kerja. Penelitian Andianto (2010) menunjukkan bahwa terdapat hubungan yang signifikan antara status gizi dengan produktivitas kerja tenaga kerja di CV. Faisal Putra. Penelitian lainnya, yang dilakukan oleh Kusuma (2011), juga menunjukkan bahwa terdapat hubungan antara status gizi dengan produktivitas kerja.

Status gizi dipengaruhi oleh konsumsi zat gizi. Suharno (1990) mengatakan perbaikan konsumsi zat gizi dapat memperbaiki status gizi. Zat gizi yang cukup penting untuk mendukung aktivitas, khususnya dalam melakukan pekerjaan adalah zat gizi penghasil energi yaitu karbohidrat, lemak, dan protein. Energi dalam jumlah besar dibutuhkan untuk kerja otot skelet yang melakukan kerja luar. Penelitian sebelumnya membuktikan bahwa terdapat hubungan antara karbohidrat, lemak, dan protein dengan status gizi, contohnya adalah penelitian yang dilakukan oleh Gumala (2011) yang menunjukkan hubungan yang bermakna antara tingkat konsumsi zat gizi (protein, lemak, dan karbohidrat) dengan status gizi pasien di BPK RS Jiwa Provinsi Bali. Penelitian yang dilakukan oleh Rokhmah, et al (2016), juga menunjukkan bahwa terdapat hubungan yang signifikan antara tingkat kecukupan protein, lemak, dan karbohidrat dengan status gizi siswi SMA di Pondok Pesantren Al-Izzah Kota Batu.

Perkebunan Kalijompo merupakan salah satu perkebunan karet di Jember. Aktivitas penyadapan pohon karet tidak hanya dilakukan oleh pekerja laki-laki tetapi juga wanita. Pekerjaan menyadap pohon karet tergolong pekerjaan berat bagi wanita. Status wanita yang juga berperan sebagai istri dan ibu, mengharuskan 
pekerja wanita penyadap getah karet memperhatikan kebutuhan sekaligus keadaan gizinya. Berdasarkan hal tersebut peneliti tertarik untuk mempelajari hubungan antara asupan karbohidrat, lemak, dan protein dengan status gizi pada pekerja wanita penyadap getah karet di Perkebunan Kalijompo Jember. Penelitian ini bertujuan untuk mempelajari hubungan antara asupan karbohidrat, lemak, dan protein dengan status gizi pada pekerja wanita penyadap getah karet di Perkebunan Kalijompo Jember.

\section{METODE PENELITIAN}

Penelitian ini bersifat observasional dengan rancang bangun cross sectional. Penelitian ini termasuk dalam penelitian lapangan yaitu dalam mengumpulkan data didapatkan melalui pengukuran secara langsung. Terkait dengan metode analisis, penelitian ini termasuk dalam penelitian analitik.

Lokasi penelitian dilaksanakan di Perkebunan Kalijompo, Kabupaten Jember. Dilaksanakan pada bulan Februari-Agustus 2017. Populasi pada penelitian ini adalah seluruh pekerja wanita penyadap getah karet di Perkebunan Kalijompo Jember yaitu sebanyak 48 orang. Teknik pengambilan sampel ditentukan dengan metode simple random sampling karena populasi pada penelitian ini homogen.

Variabel dalam penelitian ini terdiri dari dua jenis yaitu variabel independen dan variabel dependen. Variabel independen dalam penelitian ini terdiri dari asupan karbohidrat, asupan lemak, dan protein. Variabel dependen dalam penelitian ini adalah status gizi. Asupan karbohidrat, lemak, dan protein diketahui dari hasil wawancara menggunakan metode food recall 2 kali (1×24 jam). Hasil food recall dihitung berdasar asupan karbohidrat, lemak, dan protein menggunakan program Nutri Survey. Asupan keempat zat gizi responden tersebut kemudian dibandingkan dengan nilai Angka Kecukupan Gizi (AKG).
Status gizi diketahui melalui pengukuran berat badan dan tinggi badan, selanjutnya dilakukan penghitungan Indeks Massa Tubuh (IMT) yang digunakan untuk menentukan status gizi responden. Hubungan antara dua variabel tersebut diuji dengan uji korelasi Spearman $(\alpha=$ $5 \%$ ).

\section{HASIL}

\section{Asupan Karbohidrat Pekerja Wanita Penyadap Getah Karet di Perkebunan Kalijompo Jember}

Asupan karbohidrat merupakan jumlah karbohidrat per hari yang berasal dari makanan dan minuman yang dikonsumsi responden selama 2 kali (1×24 jam) terakhir. Hasilnya kemudian disesuaikan dengan kebutuhan karbohidrat sesuai AKG, sehingga dapat diketahui status responden. Responden dalam status defisit jika asupan karbohidrat responden kurang dari 70\% AKG, status kurang jika asupan karbohidrat responden 70-80\% AKG, status sedang jika asupan karbohidrat responden $80-99 \%$ AKG, dan status baik jika asupan karbohidrat responden lebih besar sama dengan 100\% AKG. Asupan karbohidrat responden terendah yaitu sebesar 176,2 gr dan asupan karbohidrat tertinggi responden sebesar 555 gr. Distribusi asupan karbohidrat responden dilihat pada Tabel 1.

Tabel 1. Distribusi Asupan Karbohidrat Pekerja Penyadap Getah Karet di Perkebunan Kalijompo Jember Tahun 2017

\begin{tabular}{|c|c|c|}
\hline Asupan Karbohidrat & $\mathbf{n}$ & $\%$ \\
\hline Defisit & 2 & 6,1 \\
\hline Kurang & 3 & 9,1 \\
\hline Sedang & 3 & 9,0 \\
\hline Baik & 25 & 75,8 \\
\hline Total & 33 & 100 \\
\hline
\end{tabular}


memiliki asupan karbohidrat yang paling baik.

\section{Asupan Lemak Pekerja Wanita Penyadap Getah Karet di Perkebunan Kalijompo Jember}

Asupan lemak merupakan jumlah lemak per hari yang berasal dari makanan dan minuman yang dikonsumsi terakhir oleh responden terhitung selama 2 kali (1x24 jam), yang dicatat menggunakan food recall. Banyaknya asupan lemak responden kemudian disesuaikan dengan kebutuhan lemak sesuai AKG, sehingga diketahui responden termasuk dalam status defisit yaitu jika asupan lemak responden adalah kurang dari $70 \%$ AKG, kurang jika asupan lemak responden berada pada rentang 70-80\%, sedang jika asupan lemak responden berkisar antara 80-99\% AKG, atau baik jika asupan lemak responden adalah lebih besar sama dengan 100\% AKG. Diketahui asupan lemak terendah dari responden adalah 7,9 gr dan tertinggi sebesar 157,3 gr. Distribusi asupan lemak responden dapat dilihat pada Tabel 2 .

Tabel 2. Distribusi Asupan Lemak Pekerja Penyadap Getah Karet di Perkebunan Kalijompo Jember Tahun 2017

\begin{tabular}{|c|c|c|}
\hline Asupan Lemak & $\mathbf{n}$ & $\%$ \\
\hline Defisit & 14 & 42,4 \\
\hline Kurang & 1 & 3 \\
\hline Sedang & 7 & 21,2 \\
\hline Baik & 11 & 33,3 \\
\hline Total & 33 & 100 \\
\hline
\end{tabular}

Berdasarkan Tabel 2, diketahui bahwa sebagian besar $(42,4 \%)$ mengalami defisit asupan lemak.

\section{Asupan Protein Pekerja Wanita Penyadap Getah Karet di Perkebunan Kalijompo Jember}

Asupan protein merupakan jumlah protein per hari yang berasal dari makanan dan minuman yang dikonsumsi oleh responden terakhir kali selama 2 kali $(1 \times 24$ jam) yanga dicatat menggunakan food recall 2 kali (1x24 jam). Hasil dari food recall tersebut dimasukkan pada Nutrisurvey untuk mengetahui asupan protein responden. Asupan protein responden tersebut kemudian dibandingkan dengan kebutuhan lemak sesuai AKG untuk menentukan statusnya yang terdiri dari status defisit yaitu jika asupan protein responden sebesa kurang dari $70 \% \mathrm{AKG}$, kurang jika asupan protein responden berada pada rentang $70-80 \%$ AKG, sedang jika asupan protein responden berkisar antara 80-99\% AKG, dan baik jika asupan protein responden adalah lebih besar sama dengan 100\% AKG. Diketahui asupan protein terendah sebesar 27,8 gr dan tertinggi 130 gr. Distribusi asupan protein responden dapat dilihat pada Tabel 3 .

Tabel 3. Distribusi Asupan Protein Pekerja Penyadap Getah Karet di Perkebunan Kalijompo Jember Tahun 2017

\begin{tabular}{lcc}
\hline \multicolumn{1}{c}{ Asupan Protein } & n & $\%$ \\
\hline Defisit & 2 & 6,1 \\
Kurang & 1 & 3 \\
Sedang & 2 & 6,1 \\
Baik & 28 & 84,8 \\
$\quad$ Total & 33 & 100 \\
\hline
\end{tabular}

Tabel 3 menunjukkan bahwa sebagian besar responden $(84,8 \%)$ memiliki asupan protein yang baik.

\section{Status Gizi Pekerja Wanita Penyadap Getah Karet di Perkebunan Kalijompo Jember}

Status gizi pada penelitian ini dilihat berdasarkan nilai IMT. Untuk menentukan IMT, dilakukan penimbangan berat badan dan pengukuran tinggi badan responden. Hasil penimbangan dan pengukuran tersebut selanjutnya dihitung menggunakan rumus IMT yang menghasilkan nilai IMT. IMT terdiri dari 5 
kategori, yang terdiri dari sangat kurus, kurus, normal, gemuk, dan sangat gemuk. Responden dikatakan sangat kurus jika nilai IMT adalah kurang dari 17,0, kurus jika nilai IMT berada pada rentang $17,0-$ 18,4 , normal jika nilai IMT berada pada rentang 18,5-25,0, gemuk jika nilai IMT berada pada rentang kurang dari 25,1-27,0, dan sangat gemuk jika nilai IMT lebih besar dari 27,0 .

Tabel 4. Distribusi Status Gizi Pekerja Wanita Penyadap Getah Karet di Perkebunan Kalijompo Jember Tahun 2017

\begin{tabular}{lcc}
\hline \multicolumn{1}{c}{ Status Gizi } & n & \% \\
\hline Kurus & 1 & 3 \\
Normal & 20 & 60,6 \\
Gemuk & 6 & 18,2 \\
Sangat gemuk & 6 & 18,2 \\
\multicolumn{1}{c}{$\quad$ Total } & 33 & 100 \\
\hline
\end{tabular}

Diketahui bahwa nilai IMT terendah dari responden adalah 18,4 dan nilai IMT tertinggi dari responden adalah
31,8. Distribusi pekerja wanita penyadap getah karet di Perkebunan Kalijompo Jember berdasarkan status gizi dapat dilihat pada Tabel 4 menunjukkan bahwa sebagian besar responden $(60,6 \%)$ memiliki status gizi normal.

\section{Hubungan Asupan Karbohidrat dengan Status Gizi pada Pekerja Wanita Penyadap Getah Karet di Perkebunan Kalijompo Jember}

Hubungan antara asupan karbohidrat dengan status gizi pada pekerja wanita penyadap getah karet di Perkebunan Kalijompo Jember dapat ditinjau berdasarkan tabulasi silang. Tabulasi silang merupakan analisis data statistik yang bersifat deskriptif dan berbentuk tabel frekuensi untuk dua variabel. Distribusi hubungan antara asupan karbohidrat dengan status gizi pada pekerja wanita penyadap getah karet di Perkebunan Kalijompo Jember dapat dilihat pada tabulasi silang pada Tabel 5 .

Tabel 5. Tabulasi Silang Antara Asupan Karbohidrat dengan Status Gizi pada Pekerja Wanita Penyadap Getah Karet di Perkebunan Kalijompo Tahun 2017

\begin{tabular}{|c|c|c|c|c|c|c|c|c|c|c|}
\hline \multirow{3}{*}{ Asupan Karbohidrat } & \multicolumn{8}{|c|}{ Status Gizi } & \multirow{2}{*}{\multicolumn{2}{|c|}{ Total }} \\
\hline & \multicolumn{2}{|c|}{ Kurus } & \multicolumn{2}{|c|}{ Normal } & \multicolumn{2}{|c|}{ Gemuk } & \multicolumn{2}{|c|}{$\begin{array}{l}\text { Sangat } \\
\text { Gemuk }\end{array}$} & & \\
\hline & $\mathbf{n}$ & $\%$ & $\mathbf{n}$ & $\%$ & $\mathbf{n}$ & $\%$ & $\mathbf{n}$ & $\%$ & $\mathbf{n}$ & $\%$ \\
\hline Defisit & 0 & 0 & 1 & 50 & 1 & 50 & 0 & 0 & 2 & 100 \\
\hline Kurang & 0 & 0 & 2 & 66,7 & 1 & 33,3 & 0 & 0 & 3 & 100 \\
\hline Sedang & 0 & 0 & 2 & 66,7 & 0 & 0 & 1 & 33,3 & 3 & 100 \\
\hline Baik & 1 & 4 & 15 & 60 & 4 & 16 & 5 & 20 & 25 & 100 \\
\hline
\end{tabular}

Berdasarkan Tabel 5 diketahui

bahwa terdapat responden yang mengalami defisit asupan karbohidrat dengan status gizi normal dan gemuk, masing-masing sebesar 50\%. Responden yang mengalami kurang asupan karbohidrat dengan status gizi normal sebesar 66,7\%. Responden dengan asupan karbohidrat sedang dan memiliki status gizi normal sebesar $66,7 \%$. Responden dengan asupan karbohidrat yang baik dan kondisi gizinya yang berstatus normal sebesar $60 \%$. Tabel 5 menunjukkan bahwa responden dengan kondisi asupan karbohidrat yang baik memiliki status gizi yang normal.

Berdasarkan hasil uji statistik menggunakan uji korelasi spearman diperoleh nilai $p=0,968$. Nilai $p$ tersebut diketahui melebihi nilai $\alpha$ yaitu sebesar 0,05 . Hal tersebut menunjukkan bahwa tidak terdapat hubungan yang signifikan antara asupan karbohidrat dengan status gizi. 


\section{Hubungan Asupan Lemak dengan status Gizi pada Pekerja Wanita Penyadap Getah Karet di Perkebunan Kalijompo Jember}

Hubungan antara asupan lemak dengan status gizi responden pada penelitian ini dapat dilihat berdasarkan hasil tabulasi silang dan uji korelasi Spearman. Hubungan antara asupan lemak dengan status gizi dapat dilihat secara deskriptif menggunakan tabulasi silang. Uji korelasi Spearman digunakan untuk mengetahui ada atau tidaknya hubungan serta mengetahui kekuatan hubungan antara kedua variabel tersebut.

Hasil penelitian menunjukkan bahwa sebagian besar asupan lemak responden berada pada kondisi defisit asupan lemak yaitu sebanyak 14 responden. Asupan lemak responden paling rendah berada pada kondisi kurang yaitu sebanyak 7 responden. Distribusi responden berdasarkan asupan lemak dan status gizi dapat dilihat pada Tabel 6.

Tabel 6. Tabulasi Silang Antara Asupan Lemak dengan Status Gizi pada Pekerja Wanita Penyadap Getah Karet di Perkebunan Kalijompo Tahun 2017

\section{Status Gizi}

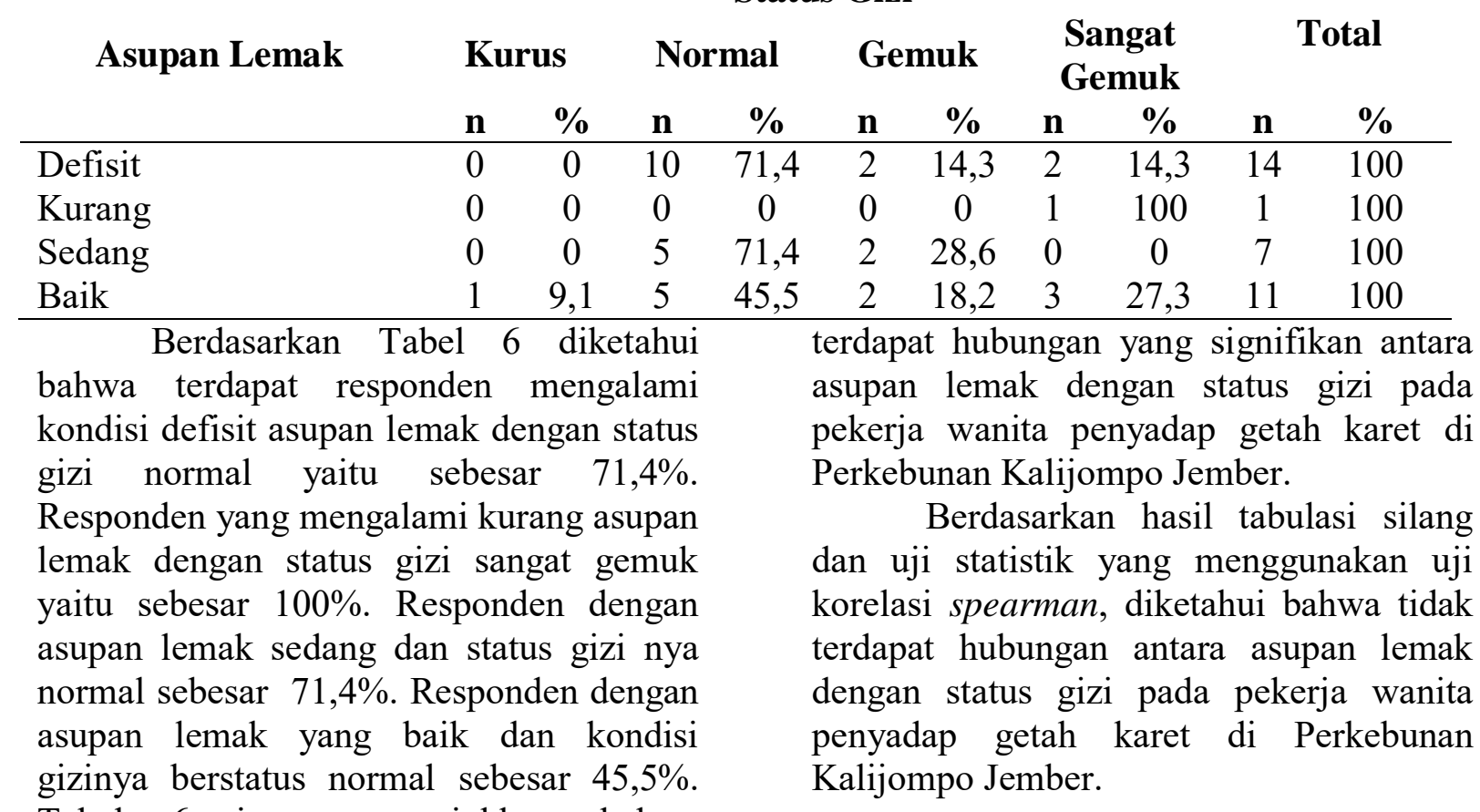

Tabel 6 juga menunjukkan bahwa responden dengan kondisi defisit asupan lemak memiliki status gizi yang normal.

Uji korelasi spearman digunakan untuk mencari hubungan atau untuk menguji signifikansi hipotesis asosiatif jika pada setiap variabel yang dihubungkan skala datanya berbentuk ordinal. Hasil uji statistik menggunakan uji korelasi spearman, diketahui nilai $p=0,646$. Nilai $p$ tersebut diketahui bahwa melebihi nilai $\alpha$ yang sebesar 0,05 . Hasil yang menunjukkan bahwa nilai $p$ melebihi nilai $\alpha$, hasil tersebut menunjukkan bahwa tidak

\section{Hubungan Asupan Protein dengan Status Gizi pada Pekerja Wanita Penyadap Getah Karet di Perkebunan Kalijompo Jember}

Uji korelasi spearman digunakan untuk mencari ada atau tidaknya hubungan antara asupan protein dengan status gizi atau untuk menguji signifikansi hipotesis asosiatif serta kekuatan hubungan antar kedua variabel tersebut. Hasil pada penelitian ini menunjukkan bahwa sebagian besar asupan protein responden 
berada pada kondisi yang baik sebanyak 28 responden. Asupan protein responden berada pada kondisi yang sedang dan defisit masing-masing sebanyak 2 responden, sedangkan asupan protein yang berada pada kondisi yang kurang hanya 1 responden saja.

Distribusi responden berdasarkan asupan protein dan status gizi dapat dilihat pada Tabel 7 berikut:

Tabel 7. Tabulasi Silang Antara Asupan Protein dengan Status Gizi pada Pekerja Wanita Penyadap Getah Karet di Perkebunan Kalijompo Tahun 2017

\begin{tabular}{|c|c|c|c|c|c|c|c|c|c|c|}
\hline \multirow{3}{*}{ Asupan Protein } & \multicolumn{8}{|c|}{ Status Gizi } & \multirow{2}{*}{\multicolumn{2}{|c|}{ Total }} \\
\hline & \multicolumn{2}{|c|}{ Kurus } & \multicolumn{2}{|c|}{ Normal } & \multicolumn{2}{|c|}{ Gemuk } & \multicolumn{2}{|c|}{$\begin{array}{l}\text { Sangat } \\
\text { Gemuk }\end{array}$} & & \\
\hline & $\mathbf{n}$ & $\%$ & $\mathbf{n}$ & $\%$ & $\mathbf{n}$ & $\%$ & $\mathbf{n}$ & $\%$ & $\mathbf{n}$ & $\%$ \\
\hline Defisit & 0 & 0 & 0 & 0 & 1 & 50 & 1 & 50 & 2 & 100 \\
\hline Kurang & 0 & 0 & 1 & 100 & 0 & 0 & 0 & 0 & 1 & 100 \\
\hline Sedang & 0 & 0 & 2 & 100 & 0 & 0 & 0 & 0 & 2 & 100 \\
\hline Baik & 1 & 3,6 & 17 & 60,7 & 5 & 17,9 & 5 & 17,9 & 28 & 100 \\
\hline
\end{tabular}

Berdasarkan Tabel 7 yang merupakan tabulasi silang, digunakan untuk analisis data yang bersifat deskriptif, diketahui bahwa terdapat responden mengalami kondisi defisit protein dengan status gizi gemuk dan sangat gemuk, masing-masing sebesar 50\%. Terdapat responden yang mengalami kurang asupan protein dengan status gizi normal yaitu sebesar 100\%. Responden dengan asupan protein sedang dan status gizi nya normal yaitu sebesar 100\%. Selanjutnya terdapat responden dengan asupan protein yang baik dan kondisi gizinya berstatus normal yaitu sebesar $60,7 \%$. Jika dilihat berdasarkan kecenderungan data pada Tabel 7, diketahui bahwa sebagian besar responden dengan kondisi asupan protein kurang dan sedang memiliki status gizi normal.

Uji korelasi spearman digunakan untuk mengetahui hubungan atau untuk menguji signifikansi hipotesis asosiatif jika pada setiap variabel yang dihubungkan skala datanya berbentuk ordinal. Berdasarkan hasil uji statistk yang menggunakan uji korelasi spearman, diketahu nilai $p=0,679$. Nilai $p$ tersebut diketahui melebihi nilai $\alpha(0,05)$. Hasil yang menunjukkan bahwa nilai $p$ melebihi $\alpha$, menunjukkan bahwa antara asupan protein dengan status gizi tidak terdapat hubungan yang signifikan. Kedua uji tersebut menunjukkan bahwa tidak terdapat hubungan antara asupan protein dengan status gizi pada pekerja wanita penyadap getah karet di Perkebunan Kalijompo Jember.

\section{PEMBAHASAN}

\section{Hubungan Asupan Karbohidrat dengan Status Gizi Pekerja Wanita Penyadap Getah Karet di Perkebunan Kalijompo Jember}

Karbohidrat adalah sumber energi utama bagi manusia yang relatif murah. Karbohidrat terdiri dari 2 golongan yaitu karbohidrat sederhana dan karbohidrat kompleks. Karbohidrat sederhana merupakan gula dan merupakan bagian alami dari beberapa makanan seperti buah, sayur, dan susu. Karbohidrat kompleks merupakan tepung. Makanan tingi karbohidrat kompleks yaitu lentil, buncis, kacang kapri, kentang, jagung, ercis, nasi, pasta, grits, seral, tepung jagung, roti, dan oatmeal (Kowtaluk, 2001).

Sebagian besar responden memperoleh asupan karbohidrat dari konsumsi nasi. Terdapat responden yang mengkonsumsi 300 gr nasi dalam 1 kali makan. Menurut penuturan responden, jika konsumsi nasi kurang maka akan membuat responden tidak kuat bekerja. Pekerjaan menyadap getah karet dapat dikatakan berat, terlebih bagi wanita (Santosa, 2004). Sebesar $40 \%$ waktu pekerja digunakan untuk berdiri 
menyadap pohon karet dan 60\% waktu digunakan untuk berjalan mengambil getah karet serta memikul ember berisi getah karet (Almatsier, 2009).

Sebagian besar responden memperoleh karbohidrat kompleks dari konsumsi nasi. Asupan karbohidrat sederhana diperoleh dari konsumsi sayur. Sebagian besar responden jarang dan bahkan tidak pernah mengkonsumsi makanan yang mengandung karbohidrat kompleks dan sederhana lainnya, seperti susu dan buah. Hal ini karena kondisi tempat tinggal responden yang berada di kaki gunung sehingga untuk memperoleh susu lebih sulit dan mahal dibandingkan memperoleh nasi dan sayur. Meskipun banyak buah yang tumbuh di lingkungan tempat tinggal responden, mereka lebih memilih untuk menjual buah tersebut dibandingkan mengkonsumsinya sendiri.

Berdasarkan Tabel 5 diketahui bahwa sebagian besar responden dengan asupan karbohidrat yang baik, sedang, kurang, dan defisit cenderung memiliki status gizi normal. Ditinjau dari hasil uji korelasi Spearman diketahui bahwa tidak terdapat hubungan yang signifikan antara asupan karbohidrat dengan status gizi.

Seseorang yang mengkonsumsi karbohidrat dalam jumlah berlebihan dapat menimbulkan kegemukan (Almatsier, 2009). Senada dengan hal tersebut, menurut Kowtaluk (2001), jumlah asupan zat gizi salah satunya adalah karbohidrat dapat menimbulkan kegemukan. Kegemukan dapat terjadi akibat konsumsi makanan yang melebihi angka kecukupan gizi (Adriani danWirjatmadi, 2012).

Karbohidrat dapat menimbulkan kegemukan. Responden dengan kondisi defisit dan kurang karbohidrat dapat tetap memiliki status gizi yang baik karena fungsi karbohidrat dalam menghasilkan energi, dibantu oleh konsumsi makanan responden yang mengandung lemak dan terutama protein. Lemak dan protein yang juga dapat menghasilkan energi, sehingga asupan energi responden sesuai dengan aktivitas yang dilakukan maka tidak terjadi masalah dengan status gizinya.
Penelitian sejenis telah banyak dilakukan sebelumnya. Penelitian yang dilakukan oleh Elnovriza (2009) menunjukkan bahwa antara asupan karbohidrat dengan status gizi tidak terdapat hubungan yang signifikan. Penelitian lainnya yang dilakukan oleh Atika, et al (2015) menunjukkan hasil bahwa tidak terdapat hubungan antara asupan karbohidrat dengan status gizi pada pelajar di SMP Negeri 13 Kota Manado.

\section{Hubungan Asupan Lemak dengan Status Gizi Pekerja Wanita Penyadap Getah Karet di Perkebunan Kalijompo Jember}

Lemak merupakan sumber energi paling padat, zat gizi ini menghasilkan 9 kalori untuk setiap gramnya yaitu 2,25 kali lebih besar energi yang dihasilkan oleh karbohidrat dan protein dalam jumlah yang sama. Lemak merupakan cadangan energi tubuh terbesar. Simpanan lemak tersebut berasal dari konsumsi salah satu atau kombinasi beberapa zat energi yaitu karbohidrat, lemak, dan protein (Almatsier, 2009). Sumber lemak berasal dari mentega, margarin, minyak tumbuh-tumbuhan (minyak kelapa, kelapa sawit, kacang tanah, kacang kedelai, dan jagung), daging, ikan, ayam, telur, susu, krim, keju, kacang-kacangan, bijibijan, alpukat, makanan yang dipanggang, dan makanan yang digoreng (Kowtaluk, 2001, dan Almatsier, 2009).

Sebagian besar responden memiliki asupan lemak yang defisit, konsumsi makanan responden yang mengandung lemak lebih sedikit dibandingkan karbohidrat dan protein. Menurut responden, dengan mengkonsumsi lebih banyak nasi yang mengandung karbohidrat jauh lebih bertenaga dibandingkan lauk pauk yang mengandung lemak. Terdapat responden yang mengkonsumsi sedikit makanan yang mengandung lemak dan keadaan tersebut diperparah dengan freukensi makan yang hanya 2 kali dalam sehari.

Makanan mengandung lemak yang sering dikonsumsi oleh sebagian besar responden adalah telur dan ikan khususnya 
ikan cakalang, pindang tongkol, teri, dan ikan asin. Selain faktor kemudahan mendapatkan makanan, faktor ekonomi juga menjadi alasan. Responden jarang mengkonsumsi makanan yang mengandung lemak khususnya daging dan ayam. Kedua makanan tersebut dianggap mewah oleh sebagian besar responden. Responden mengaku bahwa untuk mengkonsumsi kedua makanan tersebut hanya pada saat menghadiri atau mengadakan hajatan atau pada saat hari raya.

Berdasarkan Tabel 6. diketahui bahwa seluruh responden dengan kondisi kurang asupan lemak memiliki status gizi yang sangat gemuk. Sebagian besar responden dengan kondisi asupan lemak yang defisit sedang, dan baik cenderung memiliki status gizi yang normal. Ditinjau dari hasil uji korelasi Spearman diketahui bahwa tidak terdapat hubungan yang signifikan antara asupan lemak dengan karbohidrat.

Cadangan lemak yang berlebihan dapat menimbulkan seseorang memiliki berat badan lebih (Suhardjo dan Kusharto, 1992). Wanita setelah menopause akan mengalami peningkatan lemak tubuh terutama lemak pusat (Demerath, et al, 2007). Asupan lemak berpengaruh besar terhadap keseimbangan energi. Kondisi seseorang dengan asupan lemak rendah, tinggi karbohidrat, tinggi protein, konsumsi kafein, dan tinggi serat maka yang terjadi adalah energi yang masuk lebih sedikit dibandingkan energi yang keluar. Jika kondisi seseorang dengan asupan tinggi lemak, rendah karbohidrat, rendah protein, dan rendah serat maka yang terjadi adalah energi yang masuk lebih banyak dibandingkan energi yang keluar (Doucet dan Tremblay, 1997).

Responden dengan kondisi kurang asupan lemak tetapi memiliki status gizi yang gemuk atau sangat gemuk, dapat terjadi karena cadangan lemak di dalam tubuhnya yang berlebihan. Cadangan lemak yang berlebihan tanpa diimbangi dengan aktivitas yang sesuai, dapat menimbulkan kenaikan berat badan. Selain itu, menurut penuturan responden mengaku bahwa meskipun ia mengalami kegemukan, porsi dan frekuensi makannya sedikit. Selain itu, konsumsi responden terhadap kafein dari teh dan kopi khususnya, dianggap cukup untuk melakukan aktivitas menyadap getah karet. Hal tersebut sesuai dengan yang dinyatakan oleh Harpaz (2016), bahwa kafein dapat meningkatkan performa fisik dan mengurangi kelelahan, sehingga responden merasa cukup dengan konsumsi kopi dan/atau teh tanpa makan pagi dan/atau dengan prosi makan yang sedikit..

Telah banyak penelitian sejenis yang menyatakan bahwa tidak terdapat hubungan antara asupan lemak dengan status gizi. Penelitian yang dilakukan Elnovriza (2009) pada mahasiswa di asrama Universitas Andalas, menunjukkan bahwa tidak terdapat hubungan antara asupan lemak dengan status gizi. Penelitian lainnya yang dilakukan oleh Arifiyanti (2016) pada remaja putri di Pondok Pesantren Ta'mirul Islam Surakarta, juga menunjukkan bahwa tidak terdapat hubungan antara asupan lemak dengan status gizi. Senada dengan penelitan tersebut, penelitian yang dilakukan Adani, et al (2016) juga menyatakan bahwa tidak terdapat hubungan antara asupan lemak dengan status gizi.

\section{Hubungan Asupan Protein dengan Status Gizi Pekerja Wanita Penyadap Getah Karet di Perkebunan Kalijompo Jember}

Protein merupakan zat gizi penghasil energi yang relatif lebih mahal. Protein terdiri dari banyak asam amino. Berdasarkan pada kandungan asam amino, dapat dikatakan bahwa makanan yang menyediakan protein komplit dan protein inkomplit. Protein komplit mengandung asam amino esensial dalam jumlah yang cukup, beberapa makanan seperti daging, ayam, ikan, telur, susu, dan keju menyediakan protein jenis ini. Protein inkomplit, mengandung kurang atau lebih asam amino esensial, beberapa makanan seperti buncis, kacang kapri, serealia, dan kacang-kacangan menyediakan lebih banyak protein jika dibandingkan sayur dan buah (Kowtaluk, 2001). Menurut Almatsier (2009), sumber protein yang baik didapatkan dari 
bahan makanan hewani, baik dalam jumlah maupun mutunya seperti telur, susu, daging, unggas, ikan, dan kerang. Sumber protein nabati adalah kacang kedelai yang sering dihasilkan produk olahan seperti tempe dan tahu. Padi-padian serta produk hasil olahannya relatif rendah protein, akan tetapi karena dikonsumsi dalam jumlah yang banyak, maka dapat memberi sumbangan besar terhdap konsumsi protein. Makanan yang mengandung protein yang setiap hari dikonsumsi oleh sebagian besar responden adalah tahu, telur, dan ikan. Porsi makan responden terhadap makanan yang mengandung protein dapat dikatakan cukup, dalam 1 kali makan responden dapat mengkonsumsi tempe dan/atau tahu, ikan cakalang, telur, dan nasi setiap harinya.

Berdasarkan Tabel 6, diketahui bahwa seluruh responden dengan kondisi asupan protein yang kurang dan sedang, masing-masing memiliki status gizi normal. Sebagian besar responden dengan kondisi asupan protein yang baik memiliki status gizi normal. Terdapat responden dengan kondisi defisit asupan protein memiliki status gizi gemuk dan sangat gemuk. Ditinjau dari hasil uji korelasi Spearman diketahui bahwa tidak terdapat hubungan antara asupan protein dengan status gizi.

Protein merupakan salah satu zat penghasil energi selain karbohidrat dan lemak, keseimbangan energi dengan aktivitas yang dilakukan dapat memberikan berat badan yang seimbang atau normal (Kowtaluk, 2001). Berdasarkan hal tersebut, responden dengan kondisi kurang asupan protein memiliki status gizi yang normal sebagai akibat dari kebutuhan untuk asupan energi yang dibantu oleh karbohidrat dan lemak sehingga energi yang dimiliki cukup dan seimbang dengan aktivitas yang dilakukan, sehingga berat badan atau status gizi responden normal. Responden dengan kondisi defisit asupan protein tetapi memiliki status gizi yang gemuk dapat terjadi karena kebutuhan energinya tercukupi dari karbohidrat dan lemak tetapi proteinnya kurang. Responden tersebut kecukupan energi yang dimiliki lebih besar daripada aktivitas yang dilakukan, sehingga responden dapat mengalami kegemukan.

Penelitian yang dilakukan oleh Elnovriza (2009) menunjukkan bahwa tidak terdapat hubungan antara asupan protein dengan status gizi mahasiswa di asrama Universitas Andalas. Penelitian lainnya yang dilakukan pada pelajar di SMP Negeri 13 Kota Manado menunjukkan bahwa tidak terdapat hubungan antara asupan protein dengan status gizi (Atika, et al, 2015). Senada dengan hal tersebut, penelitian yang dilakukan Rinanti (2014) juga menunjukkan bahwa tidak terdapat hubungan antara asupan protein dengan status gizi.

\section{SIMPULAN}

Hasil penelitian menyatakan bahwa tidak terdapat hubungan antara asupan karbohidrat dengan status gizi pada pekerja wanita penyadap getah karet di Perkebunan Kalijompo Jember dengan nilai $\mathrm{p}=0,968$. Tidak terdapat hubungan antara lemak dengan status gizi pada pekerja wanita penyadap getah karet di Perkebunan Kalijompo Jember dengan nilai $\mathrm{p}=0,646$. Tidak terdapat hubungan antara protein dengan status gizi pada pekerja wanita penyadap getah karet di Perkebunan Kalijompo Jember dengan nilai $\mathrm{p}=0,679$. Saran yang dapat diberikan adalah pekerja agar mengurangi konsumsi kafein dari kopi dan teh, serta dapat menambah konsumsi makanan yang mengandung lemak. Pekerja dapat menyeimbangkan asupan karbohidrat, lemak, dan protein baik itu melalui jenis makanan yang lebih beragam, frekuensi makan dalam sehari agar diubah dari 2 kali sehari menjadi 3 kali sehari maupun menambah porsi makan. Pekerja perkebunan disarankan agar mengadakan cek status gizi secara rutin sehingga status gizi pekerja dapat terkontrol.

\section{DAFTAR PUSTAKA}

Adani, V., Pangestuti, D., R., and Rahfiluddin, M., Z., 2016. Hubungan Asupan Makanan (Karbohidrat, 
Protein, dan Lemak) dengan Status Gizi Bayi dan Balita (Studi pada Taman Penitipan Anak Lusendra Kota Semarang Tahun 2016). Jurnal Kesehatan Masyarakat (Online), Vol. 4., No. 3.

Andianto, B., 2010. Faktor yang Berhubungan dengan Produktivitas Kerja Tenaga Kerja di Bagian Pencetakan Kerupuk CV. Faisal Putra. Skripsi. Surabaya: Universitas Airlangga.

Adriani, M., and Wirjatmadi, B., 2012. Peranan Gizi dalam Siklus Kehidupan. Jakarta: Prenamedia Group.

Almatsier, S., 2009. Prinsip Dasar Ilmu Gizi. Jakarta: Gramedia Pustaka Utama.

Arifiyanti, A. D., 2016. Hubungan Asupan Energi dan Lemak dengan Status Gizi pada Remaja Putri di Pondok Pesantren Ta'mirul Islam Surakarta. Skripsi. Surakarta: Universitas Muhammadiyah Surakarta.

Atika, W., Punuh, M. I., and Kapantow, N.H., 2015. Hubungan Antara Asupan Energi dan Zat Gizi Makro dengan Status Gizi pada Pelajar di SMP Negeri 13 Kota Manado. Jurnal Ilmiah Farmasi (Online), Vol. 4, No. 4.

BPS. 2013. Statistik Karet Indonesia 2013. Jakarta: Badan Pusat Statistik.

Demerath, E., W., Sun, S., S., Rogers, N., Lee, M., Reed, D., Choh, A., C., Couch W., Czerwinski, S., A., Chumlea, C., Siervogel, R., M., Towne, B., 2007. Anatomical Patterning of Visceral Adipose Tissue: Race, Sex, and Age Variation. Obesity, Vol. 15, No. 12.

Departemen Gizi dan Kesehatan Masyarakat Fakultas Kesehatan Masyarakat Universitas Indonesia, 2007. Gizi dan Kesehatan Masyaraka. Jakarta: Raja Grafindo Persada.

Doucet, E., and Tremblay, A., 1997. Food Intake, Energy Balance and Body Weight Control. European Journal of Clinical Nutrition, Vol. 51.
Elnovriza, D., Bachtiar, H., and Yenrina, 2009-2010. Hubungan Pengetahuan dan Asupan Zat Gizi dengan Status Gizi Mahasiswa di Asrama Universitas Andalas. Jurnal Kesehatan Masyarakat (Online), Vol. 4, No. 1.

Gumala, N. M. Y., 2011. Tingkat Konsumsi Zat Gizi dan Status Gizi Berdasarkan Karakteristik Pasien di BPK RS Jiwa Provinsi Bali. Jurnal Ilmu Gizi (Online), Vol. 2, No 1,

Harpaz, E., Tamir, S., Weinstein, A., and Weinstein, Y., 2016. The Effect of Caffeine on Energy Balance. De Gruyter, Vol. 28, No. 1.

Kowtaluk, H., 2001. Discovering Food and Nutrition. USA: Mc Graw Hill.

Kusuma, G., D., 2011. Faktor-faktor yang Mempengaruhi Produktivitas Kerja pada Pelinting Rokok di Perusahaan Rokok Cemara Mas. Skripsi. Surabaya: Universitas Airlangga.

Rinanti, O., S., 2014. Hubungan Asupan Zat Gizi Makro dan Pengetahuan Gizi Seimbang dengan Status Gizi SiswaSiswi di SMP Muhammadiyah 1 Kartasura. Skripsi. Surakarta: Universitas Muhammadiyah Surakarta.

Rokhmah, F., Muniroh, L., and Nindya, T. S., 2016. Hubungan Tingkat Kecukupan Energi dan Zat Gizi Makro dengan Status Gizi Siswi SMA di Pondok Pesantren Al-Izzah Kota Batu. Media Gizi Indonesia (Online), Vol. 11, No. 1 ,

Santosa, G., 2004. Manajemen Keselamatan dan Kesehatan Kerja. Jakarta: Prestasi Pustaka

Suhardjo, 2005. Perencanaan Pangan dan Gizi. Jakarta: Bumi Aksara.

Suhardjo, and Kusharto, C. M., 1992. Prinsip-prinsip Ilmu Gizi. Yogyakarta: Kanisius.

Suharno, D., 1990. Gizi Kerja pada Masyarakat Kerja Sektor Informal. Jakarta: Departemen Kesehatan Republik Indonesia. 
Yudhantara, E., P., 2015. Analisis Faktorfaktor yang Mempengaruhi Capaian Produksi Tenaga Kerja Penyadap Karet di PT. Rumpun Sari Antan IV
Kecamatan Gumelar Kabupaten

Banyumas. Skripsi. Universitas

Diponegoro Semarang. 